\title{
Do Investors Value Environmental Corporate Policies? Evidence from the Australian Market
}

\author{
Mohinesh Chandra ${ }^{1}$ and Alireza Tourani-Rad ${ }^{2, *}$ \\ 1 Department of Turnaround and Restructuring, AlixPartners, New York, NY 10022, USA; \\ mohinesh.c@hotmail.com \\ 2 Department of Finance, Faculty of Business, Economics and Law, Auckland University of Technology, \\ Auckland 1010, New Zealand \\ * Correspondence: atourani@aut.ac.nz; Tel.: +64-9921-9999
}

Citation: Chandra, Mohinesh, and Alireza Tourani-Rad. 2021. Do Investors Value Environmental Corporate Policies? Evidence from the Australian Market. Journal of Risk and Financial Management 14: 124. https://doi.org/10.3390/jrfm14030124

Academic Editor: Michael McAleer

Received: 10 February 2021

Accepted: 11 March 2021

Published: 16 March 2021

Publisher's Note: MDPI stays neutral with regard to jurisdictional claims in published maps and institutional affiliations.

Copyright: (c) 2021 by the authors. Licensee MDPI, Basel, Switzerland. This article is an open access article distributed under the terms and conditions of the Creative Commons Attribution (CC BY) license (https:// creativecommons.org/licenses/by/ $4.0 /)$.

\begin{abstract}
In this paper, we explore the relationship between a firm's environmental policies and their risk-adjusted stock returns, using a sample of stock exchange-listed Australian firms over the period of 2010-2018. We observed a positive and statistically significant relationship suggesting that a firm's environmental policies partially explain their stock performance. Moreover, we found that investors in the Australian market significantly value a companies' efforts to reduce emissions, and that this primarily drives the investors' observed reaction to a firm's social corporate policies. Next, we formed portfolios and observed that portfolios formed on high environmental, social, and governance (ESG) Environmental Pillar scores consistently outperformed those formed on low-ESG Environmental Pillar scores. Overall, our results lend support to the notion that investors in the Australian market value information about a firm's social policies.
\end{abstract}

Keywords: firm performance; environmental policies; ESG scores; SRI

\section{Introduction}

The field of socially responsible investing (SRI) has been a locus of active study in the academic world since the 1990s. Much of this enduring interest has been informed by the rapid development of the subject area and the evolution of what investors, as a group, value. What appears to have piqued the interest of academics, even more, is the extensive ambiguity regarding the social responsibility and financial performance relationship despite a multitude of studies. In the past, the assessment of the SRI literature has been impaired by a lack of theory, data, and methodology (see, for example McWilliams and Siegel 2000). Indeed, the extant literature highlights the difficulty of assessing how investors will integrate sustainability data as a metric of a firm's market performance. Given the large disparities in the empirical findings, some authors posit that there is insufficient evidence to conclude that there exists a definitive association between SRI and a firm's financial performance (Ioannou and Serafeim 2011). Examining the broader context of the corporate social responsibility (CSR) literature, we find that much of the research positions itself on the premise that there exists a trade-off between the higher costs associated with CSR initiatives and the economic benefits derived from increased support from important stakeholder groups (Brown 1998; Yoon et al. 2018). As for the empirical evidence, there is an abundance of studies that have observed positive, negative, or no relationships between CSR and the financial performance of firms. Margolis et al. (2007) conducted a meta-analysis of 251 studies that investigated this relationship and found a slight incline toward a positive relationship.

In corporate sphere, there has been a shift in the paradigm of large institutions away from maximizing their bottom line at all costs and toward being more socially responsible, particularly with firms adopting more and more sustainable policies. The growing concern about climate change and the environmental impact of a firm's actions, compounded with 
mounting pressure from communities and legislators, has been reflected in the considerable attention paid to the development of robust corporate environmental policies. Echoing the same sentiment, Accenture, in collaboration with the United Nations Global Compact (UNGC), reported that $93 \%$ of 766 CEOs surveyed believe that climate change and sustainability will be integral in ensuring the going concern of their businesses (Accenture and United Nation Global Compact 2010).

In the case of Australia, the subject of this study, the introduction of Section 299(1)(f) of the Corporations Act 2001, which mandates Australian companies to report on certain aspects of their environmental performance, has put additional pressure on firms to remain transparent with their investors (Australian Government 2001). As noted by Deegan and Gordon (1996), since the enactment of Section 299, the environmental disclosures made by Australian firms have increased markedly over time. Moreover, the establishment of an organization such as Responsible Investment Association Australasia (RIAA) has been helpful in providing informative information regarding the size, growth and depth, and performance of the Australian responsible investment markets. RIAA has in excess of 300 members and manages more than AD\$9 trillion in 2020 (RIAA 2020). These developments implicate two key observations for this apparent flood of information. First, firms find that increased disclosure is associated with an ostensible increase in awareness concerning environmental issues. Second, and more importantly, they find that the degree of disclosure is directly attributable to concerns raised by environmental lobbyists regarding the environmental performance of firms, particularly those occupying polluting industries. The question we focus on here, therefore, is whether this information is considered to be decision-useful by investors' standards.

The main objective of this study is to examine if the CSR activities undertaken by Australian listed corporations add value to their shareholders. Our analysis was twofold. At the firm level, using a sample of publicly listed firms on the Australian Stock Exchange, we examined the monthly stock market performance of firms in relation to their social corporate polices, as proxied for by their environmental, social, and governance (ESG) Environmental Pillar scores. Consistent with Sahut and Pasquini-Descomps (2015), we employed an empirical version of an asset pricing model based on Carhart's fourfactor model, which has widely been considered as the best-in-class for evaluating fund performance. This allowed us to integrate ESG data and industry characteristics into a firm's market performance on a risk-adjusted basis. We observed positive and statistically significant coefficients for our primary ESG variable as well as ESG sub-scores. This finding suggests that firms that make a stronger commitment to engaging in environmentally friendly behaviors are rewarded by an increase in their value, all other things being equal. Furthermore, we found that investors in the Australian market value efforts to reduce emissions more than they value initiatives that promote sustainable resource use and innovation. At the portfolio level, we sorted firms into quartiles based on their ESG Environmental Pillar scores. We observed that a zero-cost portfolio, which is long-high-ESG score stocks and short-low-ESG score stocks, produces positive and statistically significant outperformance, or alphas, on a fairly consistent basis. This finding indicates that high-ESG score stocks consistently outperform low-ESG score stocks on a monthly risk-adjusted basis. Overall, our results suggest that investors in the Australian market favorably value information about a firm's environmental corporate policies.

Our contribution to the literature is two-fold. First, this study aims to contribute to the literature on the impact of environmental policies on firm value by studying the case of Australia. Even though the effect of ESG on the value of firms has widely been discussed in theoretical and empirical studies, the empirical results remain inconclusive. The relationship between environmental policies and financial resilience is of distinct importance for corporations given the increasing attention market participants pay to these issues. Second, we contribute to the literature by investigating the question using a novel empirical perspective. More specifically, we study the added value of enviromental 
policies by adopting a standard asset pricing model (Carhart 1997) and augmenting it by enviromental scores at the firm level.

The remainder of this paper is organized as follows. In the next section, we provide an overview of the relevant literature. Next, we outline the data and empirical methodology employed to test our hypotheses, including how we integrate ESG data into our model. A discussion of our empirical results is presented in the following section.

\section{Literature Review}

Concerning a firm's engagement in socially responsible behavior, two schools of thought endure within the extant literature. On the one hand, Friedman (1962) postulated that it is the fiduciary duty of managers to maximize the wealth of their firm's shareholders. To this effect, academics argue that maximizing the present value of the firm's future cash flows is paramount in furthering this objective. Indeed, many advocates in this camp hold that the pursuit of socially responsible initiatives above and beyond what is required by legal and regulatory authorities incurs additional costs, putting firms at a distinct economic disadvantage. Specifically, they purport that commitment to CSR activities can lead to over-investment and subsequent engagement in other projects that are divergent from those that would otherwise be in the best interests of the firm's shareholders (Aupperle et al. 1985; Barnea and Rubin 2006; Marsat and Williams 2014). Traditional economic theory dictates that the pursuit of such activities would be inconsistent with Friedman's wealth maximization principle and should therefore be avoided.

Continuing with the narrative of over-investment, Barnea and Rubin (2006) hypothesized that engagement in CSR may be a function of agency problems. They, among others (see McWilliams et al. 2006; Cheng et al. 2013), posited that a firm's managers have an incentive to invest in CSR, even more than what would fiscally make sense, in order to bolster their reputation amongst key stakeholders as a means to safeguard their roles. In a similar vein, Hemingway and Maclagan (2004) cited that managers may commit more heavily to CSR in an effort to obscure the impact of corporate misconduct. Implicit in these arguments is that engagement in CSR motivated by opportunistic behavior is likely to conceal the underlying economic value of a firm at the obvious expense of the shareholders. Therefore, it follows that positive news surrounding CSR, from the firm's perspective, should equate to bad news for shareholders, theoretically speaking. Indeed, Krüger (2015) found that the release of positive CSR news elicited a negative response from investors. Moreover, the reaction was most definitive when the news concerned communities or the environment. These findings suggest that investors view the implementation of CSR policies as value-destroying.

On the other hand, Freeman (1984), in his Stakeholder Theory of management, famously posited that it is the unequivocal duty of managers to take into consideration the concerns of all stakeholders, and not just their own shareholders, when making investment decisions. This includes, but is not limited to, customers, employees, and suppliers. Proponents of this argument claim that, in some instances, managers may need to subordinate the interests of their shareholders in favor of the interests of key stakeholders, even if it generates a deficit in the present value of a firm's cash flows (Mitchell et al. 1997; Whetten et al. 2001).

One way to reconcile this dissonance would be to observe that engagement in socially responsible behavior, in some capacity, exerts a positive influence on the present value of a firm's cash flows. Indeed, many academics postulate that the integration of CSR policies as an enduring component of corporate strategy can generate long-term, sustainable, competitive advantages that create value for shareholders. Among the more prevalent empirical findings presented in the literature, engagement in CSR can allow a firm to differentiate its product offerings (Waddock and Graves 1997; McWilliams and Siegel 2000), can reduce a firm's cost of capital (Mackey et al. 2007; Sharfman and Fernando 2008; El Ghoul et al. 2011), can improve a firm's public perception (Godfrey et al. 2009; Albuquerque et al. 2012), can grant firms access to more attractive terms of financing 
(Charlo et al. 2017), and can mitigate disciplinary action from regulatory and government authorities (Freedman and Stagliano 1991).

Extending on the latter, Freedman and Stagliano (1991) contended that companies with a higher standard for CSR would be less susceptible to adverse government or regulatory actions or sanctions caused by disclosure of corporate wrongdoing. It follows that they would also be perceived by investors as a safer investment option because they are less likely to be at the mercy of regulatory scrutiny (Sharfman and Fernando 2008; Godfrey et al. 2009). If an issue should arise, a reputation for a higher CSR standard may function as a reservoir of goodwill, in that consumer and regulatory authorities would be more willing to exercise discretion against the firm, thereby minimizing the impact on the firm's cash flows (Godfrey 2004). Consistent with this, Flammer (2012) found that firms with stronger reputations for environmental performance experience a smaller stock-price decrease following the announcement of eco-harmful behavior, lending support to the notion of this insurance-like feature.

In a recent paper, Li et al. (2019) explored stock market reactions to corporate social performance. The authors constructed a value-weighted portfolio based on the list of "100 best CSR companies in the world" published on the Forbes' website by the Reputation Institute. They observed that this portfolio yielded statistically significant annual abnormal returns of $1.81 \%$ and $1.26 \%$, by controlling for Carhart's four-factor model and the FamaFrench five-factor model, respectively.

The overarching objective of this study is to ascertain if this argument holds when examining a much narrower locus of the subject area. Specifically, we want to determine if the value-creation argument presented in the CSR literature persists when considering a firm's commitment to environmental sustainability. Having prefaced our discussion by investigating the broader context of CSR, we now look to the field of socially responsible investing (SRI) in order to formulate an expectation of what ought to be reasonable.

Socially responsible investing incorporates environmental, social, and governance (ESG) criteria into the investment decision. It represents a methodology to integrate an investor's ethical and moral concerns into their portfolio (Mănescu 2011; Lee et al. 2016). Their modus operandi is to do well by doing good, by excluding companies that do not meet their ethical constraints from their portfolios (Fernando et al. 2009). For our intents and purposes, we focused our attention on how environmental concerns factor into these decisions.

Regarding the environmental performance of firms, Heinkel et al. (2001) developed a theoretical model that shows when investors exclude polluting firms from their portfolios; these firms are penalized in terms of their cost of capital (subsequently confirmed by Sharfman and Fernando 2008) and restricted in terms of their risk-sharing options. They postulated that being shunned from the portfolios of green investors may coerce polluting firms into undertaking measures that rectify their environmental impact, assuming that it can be done on a cost-effective basis. Furthermore, their impact becomes progressively noticeable as the cost of implementing environmentally friendly policies becomes more fiscally feasible. Inherent in their analysis is that there exists a positive relationship between a firm's environmental performance and their investor following.

This exclusionary phenomenon has an even more pertinent implication. The selfimposed restriction by green investors to a specific class of stocks that satiates their ethical criteria could generate a mismatch in the supply and demand of suitable investment options. Consistent with this, the Social Investment Forum (SIF) noted that the growth of socially responsible assets supersedes that of the more traditional investments under management by a substantial amount. The resultant effect is that stock prices may diverge upward from their fair value (Sharfman and Fernando 2008). In line with this, Renneboog et al. (2008) provided empirical evidence supporting the notion that green financial assets may be overvalued, even after controlling for the lower risk that they represent to investors. Their findings suggest that socially responsible investors are willing to pay a premium for investing in financial assets that fulfil their environmental and social objectives. 
Evident in the discussions presented in this section is that arguments can be made as to why an investor may or may not value a firm's commitment to environmental sustainability. In formulating our hypotheses, we took into consideration the growing sense of urgency surrounding climate change, the increasingly rapid pace of information transfer, and ultimately, the weight of evidence in favor of each side of the debate. If we consider a firm's green corporate policies to be an adequate indicator of their commitment to environmental sustainability, then we formally state our hypotheses as follows:

Hypothesis 1 (H1). There is no significant association between a firm's environmental policies and its risk-adjusted stock returns.

Hypothesis 2 (H2). There is a significant association between a firm's environmental policies and its risk-adjusted stock returns.

We obtained ESG Environmental Pillar scores (our key independent variable) and total return index data from Thomson Reuters DataStream ${ }^{\mathrm{TM}}$ for all publicly listed companies on the Australian Stock Exchange (ASX) from 2010 to 2018, inclusive. After excluding all firms that did not meet our criterion of having ESG scores for the entire sample period, our final sample consisted of 178 unique firms, each with a total of 108 monthly observations per variable.

We collected data on the three sub-scores used in the construction of the ESG Environmental Pillar score for the same sample, as described above via Thomson Reuters DataStream $^{\mathrm{TM}}$. These were the Resource Use, Emission Reduction, and Innovation scores. The following definitions are directly taken from Refinitiv ${ }^{\mathrm{TM}}$ (2019):

The Resource Use score reflects a company's performance and capacity to reduce the use of materials, energy, or water, and to find more eco-efficient solutions by improving supply chain management.

The Emission Reduction score measures a company's commitment and effectiveness toward reducing environmental emissions in the production and operational processes.

The Innovation score reflects a company's capacity to reduce the environmental costs and burdens for its customers, thereby creating new market opportunities through new environmental technologies and processes, or eco-designed products.

\section{Model Specification}

We begin with our hypothesis that a firm's commitment to being environmentally friendly should be reflected in their market performance on a risk-adjusted basis. More specifically, we would like to elucidate if there is an association between a firm's environmental corporate policies (as proxied for by their ESG Environmental Pillar scores) and their stock returns on a risk-adjusted basis in the Australian market. We quantified the change in market value of a stock using an empirical version of an asset pricing model based on Carhart's four-factor model (Carhart 1997). Carhart's model builds upon the work of Fama and French (1993) in the asset pricing field. It integrates the momentum factor (UMD) to account for the influence of the market trend anomaly (Jegadeesh and Titman 1993) in addition to the three factors that Fama and French (1993), previously demonstrated to be instrumental in determining a stock's market price.In constructing these factors, we closely followed the way suggested by French (2019) on his website: https:/ / mba.tuck. dartmouth.edu/pages/faculty/ken.french/Data_Library/ff_portfolios.htm (accessed on 18 May 2018).

Consistent with our hypothesis, ESG Environmental Pillar scores have information content and may partially explain a firm's market performance. The rationale is that conveying such information would signal the ability of a firm to anticipate trends and mitigate risk to investors. To test this, we built upon the model proposed by Carhart (1997) by adding a fifth factor, ESG, which represents a firm's ESG Environmental Pillar score. 
We also introduced our industry control (IND) to account for contemporaneous industryspecific effects. Therefore, we specify our model as

$$
\begin{gathered}
R_{i, t}-R F_{t}=\alpha_{0}+\beta_{1} R M R F_{t}+\beta_{2} S M B_{t}+\beta_{3} H M L_{t}+\beta_{4} U M D_{t}+\beta_{5} E S G_{i, t}+ \\
\beta_{6} I N D_{i, t}+\varepsilon_{t}
\end{gathered}
$$

where:

$R M R F$ is the excess return on the market. We proxy this as the value-weighted return on the ASX All Ordinaries constituents minus the rate on the 30-day bank-accepted bills (from the ASX website);

$S M B$ is the average return on a portfolio of small-market capitalization firms minus the average return of a portfolio of big-market capitalization firms;

$H M L$ is the average return on a portfolio of high book-to-market ratio (growth) firms minus the average return of a portfolio of low book-to-market (value) ratio firms;

$U M D$ is a proxy for the momentum that is the average return on a high prior return portfolio minus the average return on a low prior return portfolio;

ESG is the Environmental Pillar score reflecting a company's overall commitment to environmentally sustainable practices. ESG considers a firm's performance in terms of emissions reduction, innovation, and sustainable resource use.

At the portfolio level, we sorted firms into quartiles on the basis of their ESG Environmental Pillar scores. We computed equally weighted returns on a monthly basis for each portfolio over a 12-month holding period. From these return series, we also calculated the monthly return on a zero-cost portfolio that is the long-high-ESG score portfolio and the short-low-ESG score portfolio for the holding period.

$$
R_{p, t}-R F_{t}=\alpha_{t}+\beta_{1} R M R F_{t}+\beta_{2} S M B_{t}+\beta_{3} H M L_{t}+\beta_{4} U M D_{t}+\varepsilon_{t}
$$

The monthly alpha for the High-Low portfolio, as described by Carhart's four-factor model (above), was tested for statistical significance to determine if the variation in green corporate policies explains the differential performance (if any) of stocks. Each of the fourquartile portfolios were re-balanced annually as new ESG information became available and we repeated the process for all years in the sample period.

\section{Empirical Findings}

Descriptive statistics of our sample are summarized in Table 1. The mean for the ESG Environmental Pillar score was 47.51 across 178 firms with the means for the Environmental Pillar sub-scores centered around this. This is consistent with the methodology employed by Refinitiv. As defined by Refinitiv (2019, p. 13), the Environmental Pillar Score $=0.32 \times$ Resource Use Score $+0.35 \times$ Emissions Score $+0.32 \times$ Innovation Score. In this methodology, each of the sub-scores have an almost equal-weighting in contributing to the total Environmental Pillar score. The standard deviation for the ESG Environmental Pillar score was 21.86. With respect to its mean, this was relatively large, implying that firms in the Australian market exhibit substantial variation in terms of committing to environmentally sustainable practices. This explanation was confirmed by observing the large spread between the maximum (97.26) and minimum (8.73) values for the ESG Environmental Pillar scores. 
Table 1. Descriptive statistics.

\begin{tabular}{ccccccc}
\hline Variables & No. of Firms & Mean & Median & Maximum & Minimum & Std. Dev. \\
\hline Stock Return $-\mathrm{R}_{\mathrm{f}}$ & 178 & -0.032 & -0.026 & 1.409 & -1.000 & 0.129 \\
$\mathrm{R}_{\mathrm{M}}-\mathrm{R}_{\mathrm{f}}$ & 500 & -0.024 & -0.019 & 0.044 & -0.125 & 0.036 \\
$\mathrm{SMB}$ & 3192 & -0.011 & -0.008 & 0.084 & -0.092 & 0.029 \\
$\mathrm{HML}$ & 3192 & -0.020 & -0.018 & 0.028 & -0.089 & 0.022 \\
UMD & 3192 & 0.095 & 0.098 & 0.132 & 0.020 & 0.016 \\
ESG & 178 & 47.514 & 46.574 & 97.258 & 8.732 & 21.856 \\
Emissions & 178 & 46.491 & 44.610 & 99.780 & 0.160 & 27.938 \\
Innovation & 178 & 47.744 & 42.310 & 99.800 & 0.160 & 22.982 \\
Resource Use & 178 & 48.854 & 46.900 & 99.750 & 0.500 & 28.297 \\
\hline
\end{tabular}

The sample includes publicly listed firms from the Australian Stock Exchange (ASX) from 2010 to 2018, inclusive.

Table 2 outlines the distribution of firms by industry within our sample and within the wider universe of all publicly listed firms in the Australian Stock Exchange (ASX). We observed that our sample was fairly homogeneous with that of the wider ASX sample, with the exception of the consumer cyclicals industry, which was over-represented in our sample, and the healthcare and technology sectors, which were both under-represented in our sample. The largest sector represented in our sample was basic materials, accounting for $28.25 \%$ of the overall representation. Moreover, firms occupying traditionally environmentally unfriendly sectors (e.g., basic materials, industrials, and energy) constituted $52.54 \%$ of our sample, which explains the observed low-mean Environmental Pillar score in our sample.

Table 2. Distribution of firms by industry.

\begin{tabular}{|c|c|c|c|c|c|}
\hline No of Firms & Basic Materials & Consumer Cyclicals & Consumer Non-Cyclicals & Energy & Financials \\
\hline \multirow[t]{2}{*}{ Sample } & 50 & 23 & 8 & 24 & 31 \\
\hline & $28.25 \%$ & $12.99 \%$ & $4.52 \%$ & $13.56 \%$ & $17.51 \%$ \\
\hline \multirow[t]{3}{*}{ ASX } & 1004 & 218 & 153 & 330 & 522 \\
\hline & $31.46 \%$ & $6.83 \%$ & $4.78 \%$ & $10.34 \%$ & $16.34 \%$ \\
\hline & Healthcare & Industrials & Technology & Telecommunications & Utilities \\
\hline \multirow[t]{2}{*}{ Sample } & 8 & 19 & 5 & 2 & 7 \\
\hline & $4.52 \%$ & $10.73 \%$ & $2.82 \%$ & $1.13 \%$ & $3.95 \%$ \\
\hline \multirow[t]{2}{*}{ ASX } & 255 & 283 & 343 & 44 & 40 \\
\hline & $8.00 \%$ & $8.88 \%$ & $10.73 \%$ & $1.37 \%$ & $1.27 \%$ \\
\hline
\end{tabular}

This table describes the distribution of firms by industry for both our sample and the broader context of the Australian Stock Exchange (ASX). Distribution is reported in absolute terms (the number of firms occupying a particular industry) and in relative terms (the percentage of an industry's representation relative to the overall sample). The number of firms in our sample sums to 178, and to 3192 for the ASX.

As described in the methodology section, we investigated the impact of environmental performance at the firm level, proxied for by ESG Environmental Pillar scores on a firm's excess stock returns, as described by Carhart's four-factor model. The coefficients presented in Table 3 were estimated using the generalized least squares (GLS) regression and corresponding t-statistics (in parenthesis) and adjusted following Newey and West's methodology. 
Table 3. Regression analysis.

\begin{tabular}{|c|c|c|c|c|}
\hline \multirow{2}{*}{$\begin{array}{c}\text { Variables } \\
\text { Constant }\end{array}$} & \multicolumn{4}{|c|}{ Coefficients } \\
\hline & $\begin{array}{c}-0.002 \\
(-0.229)\end{array}$ & $\begin{array}{l}-0.002 \\
(-0.192)\end{array}$ & $\begin{array}{c}0.002 \\
(0.235)\end{array}$ & $\begin{array}{c}0.002 \\
(0.169)\end{array}$ \\
\hline$R_{M}-R_{f}$ & $\begin{array}{l}1.037^{* * *} \\
(16.571)\end{array}$ & $\begin{array}{l}1.036^{* * *} \\
(16.560)\end{array}$ & $\begin{array}{l}1.038^{* * *} \\
(16.716)\end{array}$ & $\begin{array}{l}1.037^{* * *} \\
(16.601)\end{array}$ \\
\hline SMB & $\begin{array}{c}0.409 * * * \\
(4.045)\end{array}$ & $\begin{array}{c}0.409 * * * \\
(4.050)\end{array}$ & $\begin{array}{c}0.410 * * * \\
(4.082)\end{array}$ & $\begin{array}{l}0.41^{* * *} \\
(4.057)\end{array}$ \\
\hline HML & $\begin{array}{c}0.516^{* * *} \\
(4.227)\end{array}$ & $\begin{array}{c}0.516^{* * *} \\
(4.238)\end{array}$ & $\begin{array}{c}0.518^{* * *} \\
(4.269)\end{array}$ & $\begin{array}{c}0.518^{* * *} \\
(4.249)\end{array}$ \\
\hline UMD & $\begin{array}{c}-0.02 \\
(-0.235)\end{array}$ & $\begin{array}{l}-0.018 \\
(-0.206)\end{array}$ & $\begin{array}{l}-0.031 \\
(-0.357)\end{array}$ & $\begin{array}{c}-0.027 \\
(-0.315)\end{array}$ \\
\hline Industry & $\begin{array}{c}0.001 * * \\
(2.097)\end{array}$ & $\begin{array}{l}0.001 \text { ** } \\
(2.265)\end{array}$ & $\begin{array}{l}0.001 \text { ** } \\
(2.030)\end{array}$ & $\begin{array}{l}0.001 \text { ** } \\
(2.163)\end{array}$ \\
\hline ESG & $\begin{array}{c}0.000172^{* * * *} \\
(3.546)\end{array}$ & & & \\
\hline Emissions & & $\begin{array}{c}0.000154^{* * *} \\
\quad(3.930)\end{array}$ & & \\
\hline Innovation & & & $\begin{array}{c}9.22 \times 10^{-5 *} \\
(1.950)\end{array}$ & \\
\hline Resource Use & & & & $\begin{array}{c}9.32 \times 10^{-5 * *} \\
(2.403)\end{array}$ \\
\hline Observations & 19224 & 19224 & 19224 & 19224 \\
\hline Adjusted $\mathrm{R}^{2}$ & 0.1111 & 0.1114 & 0.1106 & 0.1107 \\
\hline
\end{tabular}

This table presents the results from the panel regression on our dataset. Coefficients were estimated using panel-estimated generalized least squares regression (EGLS) based on a linear model derived from Carhart's four-factor model, after controlling for period-fixed effects: $R_{i, t}-R F_{t}=\alpha_{0}+\beta_{1} R_{M R F_{t}}+\beta_{2} \mathrm{SMB}_{t}+\beta_{3} \mathrm{HML}_{t}+$ $\beta_{4} \mathrm{UMD}_{\mathrm{t}}+\beta_{5} \mathrm{ESG}_{\mathrm{i}, \mathrm{t}}+\beta_{6} \mathrm{IND}_{\mathrm{i}, \mathrm{t}}+\varepsilon_{\mathrm{t}}$. Variable definitions are provided in Appendix A. For subsequent iterations of this model, the ESG variable was substituted for each of its sub-scores (emissions, innovation, and resource use) independently. T-statistics based on Newey-West corrected standard errors are reported in parenthesis. *,**, and ${ }^{* * *}$ denote statistical significance at the $10 \%, 5 \%$, and $1 \%$ levels, respectively.

As anticipated, the market volatility exhibited the highest positive coefficient (1.037) that significantly contributes toward the stock's excess return. We also observed a high degree of statistical significance for the other traditional factors, with a positive coefficient for SMB (0.409) and a positive coefficient for HML (0.516), consistent with the empirical evidence in regard to the Fama and French models. The coefficient for the momentum factor was slightly negative $(-0.020)$ and statistically insignificant for our sample. These features were persistent across all iterations of our first model. Subsequently, we observed that the coefficient of the ESG Environmental Pillar score was positive and statistically significant at the $1 \%$ level $(t=3.456)$, albeit very low in magnitude. This finding suggests that firms that make a stronger commitment to engaging in environmentally friendly behaviors are rewarded by an increase in excess returns, all things else being held equal.

We then explored the influence of each ESG sub-score individually on the stock's excess return, as described by our first model. Following the same specification, we observed that all three sub-scores had positive and statistically significant coefficients. The coefficient on the emissions sub-score was the highest in magnitude, and also the only one that was statistically significant at the $1 \%$ level $(t=3.930)$, consistent with the empirical evidence found by Nishitani and Kokubu (2012). The estimation for resource use was significant at the $5 \%$ level, while innovation was only significant at the $10 \%$ level. Taken together, these results imply that investors in the Australian market value efforts to reduce emissions more than they value initiatives that promote sustainable resource use and innovation. More importantly, this result implies that efforts to reduce emissions are the driving force behind the observed environmental performance valuation effect. This may be a logical response by investors given the abundance of firms belonging to polluting industries within the Australian stock market.

Table 4 summarizes the analyses of equally-weighted portfolios formed by sorting on the ESG Environmental Pillar score. The average equally-weighted monthly returns 
per year for each ESG quartile and their respective outperformance, or alphas, relative to Carhart's four-factor model for zero-cost portfolios, which is the long-high-ESG score portfolio and the short-low-ESG score portfolio (row labelled High-Low) are presented in decimal form. The corresponding t-statistics reported in parenthesis were adjusted following Newey and West.

Table 4. Portfolio Analysis.

\begin{tabular}{cccccccccc}
\hline Portfolios & $\mathbf{2 0 1 0}$ & $\mathbf{2 0 1 1}$ & $\mathbf{2 0 1 2}$ & $\mathbf{2 0 1 3}$ & $\mathbf{2 0 1 4}$ & $\mathbf{2 0 1 5}$ & $\mathbf{2 0 1 6}$ & $\mathbf{2 0 1 7}$ & $\mathbf{2 0 1 8}$ \\
\hline High & -0.0003 & -0.0156 & 0.0102 & 0.0083 & 0.0053 & 0.0027 & 0.0148 & 0.0111 & -0.0093 \\
2 & 0.0061 & -0.0238 & -0.0006 & -0.0103 & -0.0126 & -0.0007 & 0.0200 & 0.0079 & -0.0074 \\
3 & 0.0122 & -0.0211 & 0.0032 & -0.0061 & -0.0142 & -0.0153 & 0.0068 & 0.0042 & -0.0116 \\
Low & 0.0118 & -0.0316 & -0.0017 & -0.0168 & -0.0176 & -0.0154 & 0.0114 & 0.0139 & -0.0165 \\
High-Low & -0.0121 & $0.0159 * * *$ & $0.0119^{*}$ & $0.0251^{* *}$ & 0.0228 & 0.0181 & $0.0034^{* *}$ & $-0.0028^{*}$ & 0.0071 \\
$(\alpha)$ & $(-0.602)$ & $(4.282)$ & $(1.906)$ & $(2.067)$ & $(0.166)$ & $(0.677)$ & $(2.146)$ & $(-1.859)$ & $(0.950)$ \\
\hline
\end{tabular}

This table reports the yearly alphas for the portfolios of stocks formed based on their ESG Environmental Pillar scores. High denotes the highest Environmental Pillar score quartile; 2 denotes the second highest Environmental Pillar score quartile; 3 denotes the third highest Environmental Pillar score quartile, and Low denotes the lowest Environmental Pillar score quartile. The alphas reported are those described by Carhart's four-factor model: $R_{p, t}-R_{t}=\alpha_{0}+\beta_{1} R_{M R F}+\beta_{2} S_{M B}+\beta_{3} H_{M L}+\beta_{4} U M D_{t}+\varepsilon_{t}$. T-statistics based on the Newey-West corrected standard errors are reported in parenthesis. ${ }^{*}, * *$, and ${ }^{* * *}$ denote statistical significance at the $10 \%, 5 \%$, and $1 \%$ levels, respectively.

We demonstrated that portfolios formed on high-ESG Environmental Pillar scores can earn as much as $2.51 \%$ above portfolios formed on low-ESG Environmental Pillar scores on a monthly risk-adjusted basis, confirming the findings by Derwall et al. (2005). Furthermore, a zero-cost portfolio that is the long-high-ESG score stocks and the shortlow-ESG score stocks consistently produces a positive outperformance in seven out of nine periods, with four of these being statistically significant at the $10 \%$ level or greater. Overall, the results in this section suggest that investors in the Australian market value information about a firm's social corporate policies.

\section{Conclusions}

The question of whether environmental performance translates into financial performance has been greeted with mixed results in the extant literature. The question of whether investors value firms that pursue such social objectives is even more divisive. The purpose of this article is to ascertain if investors within the Australian market value information concerning a firm's green corporate policies.

We explored the relationship between a firm's environmental policies and their riskadjusted stock returns. At the firm level, we observed a positive and statistically significant coefficient for the ESG Environmental Pillar score, suggesting that a firm's environmental policies partially explain their stock performance. Moreover, we found that investors in the Australian market significantly value a companies' efforts to reduce emissions, and that this primarily drives the investors' observed reaction to a firm's environmental policies.

At the portfolio level, we observed that portfolios formed on high-ESG Environmental Pillar scores consistently outperformed those formed on low-ESG Environmental Pillar scores.

Overall, the results of this study lend support to the notion that investors in the Australian market value information about a firm's environmental and social policies. To the same effect, these results directly support the value-enhancing perspective presented in the CSR and SRI literature.

Author Contributions: Data curation, M.C. and A.T.-R., formal analysis, M.C. and A.T.-R.; methodology, M.C. and A.T.-R., writing, review, and editing, M.C. and A.T.-R. All authors have read and agreed to the published version of the manuscript.

Funding: This research received no external funding. 
Data Availability Statement: Databases used for this study are subscribed to and available Auckland University of Technology to its staff and students.

Conflicts of Interest: The authors declare no conflict of interest.

\section{Appendix A. Variable Definition}

\begin{tabular}{|c|c|}
\hline Variable & Definition \\
\hline Stock Return $-R_{f}$ & $\begin{array}{l}\text { The excess return of a stock. Calculated as a firm's stock return minus the } \\
\text { risk-free rate of return as proxied for by the monthly rate on Australian } \\
\text { 30-day Bank Accepted Bills }\end{array}$ \\
\hline $\mathrm{R}_{\mathrm{M}}-\mathrm{R}_{\mathrm{f}}$ & $\begin{array}{c}\text { The market risk premium. Calculated as the market return as proxied for } \\
\text { by the value-weighted return on the ASX All Ordinaries constituents } \\
\text { minus the risk-free rate of return as proxied for by the monthly rate on } \\
\text { Australian 30-day Bank Accepted Bills. }\end{array}$ \\
\hline SMB & $\begin{array}{l}\text { Small Minus Big. Calculated as the average return on small portfolios } \\
\text { minus the average return on big portfolios (French 2019). }\end{array}$ \\
\hline HML & $\begin{array}{l}\text { High Minus Low. Calculated as the average return on value portfolios } \\
\text { minus the average return on growth portfolios (French 2019). }\end{array}$ \\
\hline UMD & $\begin{array}{l}\text { Up Minus Down. Calculated as the average return on the high prior } \\
\text { return portfolios minus the average return on the low prior return } \\
\text { portfolios (French 2019). }\end{array}$ \\
\hline ESG & $\begin{array}{c}\text { The ESG Environmental Pillar score. Reflects a company's overall } \\
\text { commitment to environmentally sustainable practices. Considers a firm's } \\
\text { performance in terms of Emissions Reduction, Innovation and } \\
\text { Sustainable Resource Use. }\end{array}$ \\
\hline Emissions & $\begin{array}{l}\text { The Emission Reduction Score measures a company's commitment and } \\
\text { effectiveness towards reducing environmental emissions in the } \\
\text { production and operational processes. }\end{array}$ \\
\hline Innovation & $\begin{array}{l}\text { The Innovation Score. Reflects a company's capacity to reduce the } \\
\text { environmental costs and burdens for its customers, thereby creating new } \\
\text { market opportunities through new environmental technologies and } \\
\text { processes or eco-designed products }\end{array}$ \\
\hline Resource Use & $\begin{array}{l}\text { The Resource Use Score. Reflects a company's performance and capacity } \\
\text { to reduce the use of materials, energy, or water, and to find more } \\
\text { eco-efficient solutions by improving supply chain management. }\end{array}$ \\
\hline
\end{tabular}

\section{References}

Accenture and United Nation Global Compact. 2010. A New Era of Sustainability: UN Global Compact-Accenture CEO Study. Available online: https:/ / www.unglobalcompact.org/library/230 (accessed on 15 March 2021).

Albuquerque, Rui, Art Durnev, and Yrjo Koskinen. 2012. Corporate Social Responsibility and Asset Pricing in Industry Equilibrium. Working Paper. Available online: https:/ / papers.ssrn.com/sol3/papers.cfm?abstract_id=1961971 (accessed on 15 March 2021).

Aupperle, Kenneth E., Archie B. Carroll, and John D. Hatfield. 1985. An empirical examination of the relationship between corporate social responsibility and profitability. Academic Management Journal 28: 446-63.

Australian Government. 2001. Corporations Act 2001. Available online: https://www.legislation.gov.au/Details/C2018C00424 (accessed on 1 October 2019).

Barnea, Amir, and Amir Rubin. 2006. Corporate social responsibility as a conflict between shareholders. Paper presented at EFA 2006 Zurich Meetings, Zurich, Switzerland, August 23-26.

Brown, Brad. 1998. Do Stock Market Investors Reward Companies with Reputations for Social Performance? Corporate Reputation Review 1: 271-80. [CrossRef]

Carhart, M. 1997. On Persistence in Mutual Fund Performance. The Journal of Finance 52: 57-82. [CrossRef]

Charlo, Maria J., Ismael Moya, and Ana M. Muñoz. 2017. Financial performance of socially responsible firms: The short- and long-term impact. Sustainability 9: 1622. [CrossRef]

Cheng, Haw, Harrison Hong, and Kelly Shue. 2013. Do Managers Do Good with Other People's Money? Unpublished Working Paper. Cambridge: Darthmouth College, Princeton University, and University of Chicago. 
Deegan, Craig, and Ben Gordon. 1996. A Study of the Environmental Disclosure Practices of Australian Corporations. Accounting and Business Research 26: 187-99. [CrossRef]

Derwall, Jeroen, Nadja Guenster, Rob Bauer, and Kees Koedijk. 2005. The eco-efficiency premium puzzle. Financial Analysts Journal 61: 61-63. [CrossRef]

El Ghoul, Sadok, Omrane Guedhami, Chuck C.Y. Kwok, and Dev R. Mishra. 2011. Does corporate social responsibility affect the cost of capital? Journal of Banking \& Finance 35: 2388-406.

Fama, Eugene F., and Kenneth R. French. 1993. Common risk factors in the returns on bonds and stocks. Journal of Financial Economics 33: 3-53. [CrossRef]

Fernando, Chitru S., Mark P. Sharfman, and Vahap B. Uysal. 2009. Do Investors Want Firms to be Green? Environmental Performance, Ownership and Stock Market Liquidity. In Academy of Management Proceedings. Briarcliff Manor: Academy of Management.

Flammer, Caroline. 2012. Corporate Social Responsibility and Shareholder Reaction: The Environmental Awareness of Investors. The Academy of Management Journal 56: 758-81. [CrossRef]

Freedman, Martin, and A. J. Stagliano. 1991. Differences in social cost disclosures: A market test of investor relations. Accounting, Auditing and Accountability Journal 4: 68-83. [CrossRef]

Freeman, R. Edward. 1984. Strategic Management: A Stakeholder Approach. Boston: Pitman, ISBN 978-0-273-01913-8.

French, K. 2019. Description of Fama/French Benchmark Factors. Available online: http:/ / mba.tuck.dartmouth.edu/pages/faculty/ ken.french/Data_Library/f-f_bench_factor.html (accessed on 1 October 2019).

Friedman, Milton. 1962. Capitalism and Freedom. Chicago: University of Chicago Press.

Godfrey, Paul C. 2004. The relationship between corporate philanthropy and shareholder wealth: A risk management perspective. Academy of Management Review 30: 777-98. [CrossRef]

Godfrey, Paul C., Craig B. Merrill, and Jared M. Hansen. 2009. The relationship between corporate social responsibility and shareholder value: An empirical test of the risk management hypothesis. Strategic Management Journal 30: 425-45. [CrossRef]

Heinkel, Robert, Alan Kraus, and Josef Zechner. 2001. The Effect of Green Investment on Corporate Behavior. Journal of Financial and Quantitative Analysis 36: 431-49. [CrossRef]

Hemingway, Christine A., and Patrick W. Maclagan. 2004. Managers' personal values as drivers of corporate social responsibility. Journal of Business Ethics 50: 33-44. [CrossRef]

Ioannou, Ioannis, and George Serafeim. 2011. The Consequences of Mandatory Corporate Sustainability Reporting. Working Paper. Boston: Harvard Business School.

Jegadeesh, Narasimhan, and Sheridan Titman. 1993. Returns to buying winners and selling losers: Implications for stock market efficiency. Journal of Finance 48: 65-91. [CrossRef]

Krüger, Philipp. 2015. Corporate goodness and shareholder wealth. Journal of Financial Economics 115: 304-29.

Lee, Ki-Hoon, Beom Cheol Cin, and Eui Young Lee. 2016. Environmental Responsibility and Firm Performance: The Application of an Environmental, Social and Governance Model. Business Strategy and the Environment 25: 40-53. [CrossRef]

Li, Zhichuan (Frank), Dylan B. Minor, Jun Wang, and Chong Yu. 2019. A learning curve of the market: Chasing alpha of socially responsible firms. Journal of Economic Dynamics E Control 109: 103772.

Mackey, Alison, Tyson B. Mackey, and Jay B. Barney. 2007. Corporate Social Responsibility and Firm Performance: Investor Preferences and Corporate Strategies. The Academy of Management Review 32: 817-35. [CrossRef]

Mănescu, Cristiana. 2011. Stock Returns in Relation to Environmental, Social and Governance Performance: Mispricing or Compensation for Risk? Sustainable Development 19: 95-118. [CrossRef]

Margolis, Joshua D., Hillary Anger Elfenbein, and James P. Walsh. 2007. Does it pay to be good? A meta-analysis and redirection of research on the relationship between corporate social and financial performance. Working paper, SSRN. Available online: https:/ / papers.ssrn.com/sol3/papers.cfm?abstract_id=1866371 (accessed on 15 March 2021).

Marsat, Sylvain, and Benjamin Williams. 2014. Does the market value social pillar? Working Paper, SSRN. Available online: https: / / papers.ssrn.com/sol3/papers.cfm?abstract_id=2419387 (accessed on 15 March 2021).

McWilliams, Abagail, and Donald Siegel. 2000. Corporate social responsibility and financial performance: Correlation or misspecification? Strategic Management Journal 21: 603-9. [CrossRef]

McWilliams, Abagail, Donald S. Siegel, and Patrick M. Wright. 2006. Guest editors' introduction corporate social responsibility: Strategic implications. Journal of Management Studies 43: 1-18. [CrossRef]

Mitchell, Ronald K., Bradley R. Agle, and Donna J. Wood. 1997. Toward a theory of stakeholder identification and salience: Defining the principle of who and what really counts. Academy of Management Review 22: 853-86. [CrossRef]

Nishitani, Kimitaka, and Katsuhiko Kokubu. 2012. Why does the reduction of greenhouse gas emissions enhance firm value? The case of Japanese manufacturing firms. Business Strategy and the Environment 21: 517-29. [CrossRef]

Refinitiv. 2019. Environmental, Social and Governance (ESG) Scores from Refinitiv. Available online: https://www.refinitiv.com/ content/dam/marketing/en_us/documents/methodology/esg-scores-methodology.pdf (accessed on 1 October 2019).

Renneboog, Luc, Jenke Ter Horst, and Chendi Zhang. 2008. Socially Responsible Investments: Institutional Aspects, Performance, and Investor Behavior. Journal of Banking and Finance 32: 1723-42. [CrossRef]

RIAA. 2020. Available online: https://responsibleinvestment.org/wp-content/uploads/2020/09/RIAA-RI-Benchmark-ReportExecutive-Summary-Australia-2020.pdf (accessed on 10 February 2021). 
Sahut, Jean-Michel, and Hélène Pasquini-Descomps. 2015. ESG Impact on Market Performance of Firms: International Evidence. Working Paper. Paris: IPAG Business School.

Sharfman, Mark P., and Chitru S. Fernando. 2008. Environmental risk management and the cost of capital. Strategic Management Journal 29: 569-92. [CrossRef]

Social Investment Forum (SIF). 2007. 2007 Report on Socially Responsible Investing Trends in the United States, SIF Executive Summary. Available online: www.socialinvest.org/pdf/SRI_Trends_ExecSummary_2007.pdf (accessed on 1 October 2019).

Waddock, Sandra A., and Samuel B. Graves. 1997. The corporate social performance-financial performance link. Strategic Management Journal 18: 303-19. [CrossRef]

Whetten, David A., Gordon Rands, and Paul Godfrey. 2001. What are the responsibilities of business to society? Handbook of Strategy and Management, 373-410.

Yoon, Bohyun, Jeong Hwan Lee, and Ryan Byun. 2018. Does ESG Performance Enhance Firm Value? Evidence from Korea. Sustainability 10: 3635 . 